\title{
TAX REFORM AND TAX INCENTIVES
}

\author{
RAIPH S. RICE*
}

\section{INTRODUCTION}

National introspection respecting tax reform was an obsession of the 1960 , in the law reviews as elsewhere. This may be expected to continue and intensify during the I970s, however much the Tax Reform Act of 1969 reminds us that even the most articulate academic anguish seldom solves questions of practical politics. Since who pays how much tax is one of the most practical of political issues, the views of academics about tax reform are not likely to be compelling. But in the hope that symposia like this one may contribute to the water that wears away the rock, let us consider yet again that aspect of tax reform which is concerned with tax incentives.

First we must note that, notwithstanding the widespread criticism of tax incentives noted hereafter in these comments, Congress in the Tax Reform Act of I969 embarked on new adventures in the creation of such tax shelters. To catalogue a few, new depletion allowances for oil shale $e^{1}$ and production from continental shelf areas $^{2}$ were adopted. Accelerated depreciation, a device long favored by those having the political muscle to obtain it, has been extended to pollution control facilities ${ }^{3}$ and railroad rolling stock. ${ }^{4}$ Tax-free roll-over of investments in low-cost housing has also been authorized." When the use of tax incentives is blindly followed even in a "tax

- Connell Professor of Law, University of Los Angeles.

1 Tax Reform Act of 1969, Pub. L. No. 91-I72, $\$ 502$ (Dec. 30, 1969), amending INT. Rev. CodB of $\mathrm{I}_{954}, \S 6 \mathrm{I}_{3}(\mathrm{c})(4)$. [The INT. REv. CODE of I954 is hereinafter cited as CODE.]

${ }^{2}$ Tax Reform Act of $1969, \S 505$, adding CODE $\$ 638$.

${ }^{3}$ Tax Reform Act of 1969 , $\$ 704$, amending Cone $\S \mathrm{r} 69$.

4 Tax Reform Act of $x 969$, $\$ \$ 705-06$, adding CODE $\$ \$ 184-85$, and amending CODE $\$ 263$.

Tax Reform Act of 1969 , $\$ 910$, adding CODE $\$$ 1039. See also $\$ 707$ of the act, adding CoDE $\S \mp 87$, accelerating depreciation as to coal mine safety equipment.

Note the following catalogue of tax incentives listed by Senator Robert Kennedy during the hearings before the Committee on Finance respecting S. 2100, goth Cong., Ist Sess. (rg67), the so-called KennedySmathers bill proposing tax incentives with respect to urban housing:

"I have a list here of situations in which tax incentives have been used. I can mention other cases in which tax credits have been used. Senator Smathers touched on some of these examples briefly. They are as follows:

(I) Accelerated depreciation in 1954 to stimulate investment in the American economy.

(2) Additional first year depreciation grants to aid small business in 1958 .

...

(3) Reduction [sic] for research and experimental expenditures;

(4) Intangible drilling costs, exploration and developmental costs for mining and percentage depletion-all of these are incentives for the discovery and exploitation of mineral resourecs;

(5) Deductions for charitable contributions;

(6) Deductions of tax and interest to promote home-ownership;

(7) Tax benefits to encourage the use of private pension plans;

(8) Tax benefits for various organizations to promote certain religious and charitable activities;

(9) Rapid amortization to encourage the production of grain storage facilities;

(10) Stock options to encourage key employee ownership; 
reform" act for which so much morality has been claimed, it is in order to take another look at their possible use in the future.

In view of the nature of this symposium, comments on this broad subject must be pitched at a high level of generalization. The initial objective of the following comments is to consider some of the preliminary questions that must be answered before we can judge the desirability of a specific incentive.

\section{The Nature of Tax Incentrves}

Tax incentives are usually thought of in simple forms such as those exemplified by the use of depletion allowances and accelerated depreciation in the 1969 act. In essence these represent a form of excrescence on the tax structure, justified by social or economic needs thought to be particularly pressing. It is important to remember, however, that the use of tax laws to promote conduct considered to be desirable is far broader and embraces the entire tax structure. We do not consider as tax incentives provision such as those incorporated in the Ig69 act to increase personal exemptions from $\$ 600$ to $\$ 75^{\circ}$ or to raise the allowable amount of the standard deduction. ${ }^{7}$ But we should remember that the basic justification for such amendments must be tested by the same political, social, and economic objectives and in substantially the same manner as we decide whether a tax incentive for pollution control or mine safety is appropriate.

In short, the following considerations are relevant:

(I) Every taxing statute represents to the persons affected by it an incentive or disincentive to some degree.

(2) The essence of a tax incentive is that someone gets an advantage at the expense of the taxpaying public; the advantage is given to him (at least ostensibly) to induce conduct beneficial to society.

(3) Every time Congress confers a tax incentive (or for that matter fails to give an incentive or enacts a disincentive) this affects the balance between members of the pool of taxpayers; some will pay more and some will pay less.

(II) Favorable tax treatment for Western' Hemisphere trade corporations;

(I2) Deductions for the premiums for paying health insurance;

(13) And just recently passed in Congress, a tax credit for investment to Thailand.

"It seems we can use the code for other social and economic objectives and for investments

in Thailand and Israel. Then why cannot we use it for other areas where we need it so greatly?" Hearings on S. 2100 Before the Senate Comm. on Finance, 90th Cong., Ist Sess. 158-59 (r967) [hereinafter cited as Hearings on S. 2200]. For other examples, see Blum \& Bursler, Tax Subsidies for Rental Housing, 15 U. Crr. L. Rev. 255 (1948); Blum \& Dunham, Income Tax Law and Slums: Some Further Reflections, 60 Colus. L. REv. 447 (r960).

- Tax Reform Act of 1969, $\$ 801$, amending CODE $\$ \S$ I5x \& 6013(b)(3)(A).

${ }^{7}$ Tax Reform Act of $\mathrm{rg69}$, § 802, amending CODE $\$$ I 4 I. 
So when we think of things generally considered to represent tax incentives we are really dealing, though many do not recognize this, with the same kind of decision that is made when, for example, we decide to have a ten per cent surtax.

It follows that in this essay it is necessary to discuss the objectives of taxation in order that specific proposals with respect to tax reform and tax incentives may be weighed. An elementary recital, including a few critical observations, is all that is attempted here. The following comments are embarrassingly simple, yet they are indispensable to any understanding of the subject.

\section{II}

\section{The Objectrves of the Tax Structure}

Establishment of tax objectives has preoccupied many economists and some tax lawyers over a long period of time. The reasons are obvious: It would be very simple if we could believe that however irrational the tax structure, and however unrelated and irregular its parts, all shortcomings may be remedied if we can only establish the proper objectives of taxation and conform the structure to the ideal. Even those who do not share this illusion will concede that criticism of the tax structure would be much more rational if we had a clearer idea of what we were trying to do.

There are obvious difficulties with this somewhat superficial approach. One problem, to which reference will be made repeatedly in these comments, is that the basic objectives of the tax structure are not consistent; pursuit of one objective often makes more difficult the accomplishment of another. ${ }^{8}$ To state the most obvious example, the imposition of any federal income tax at all necessarily reduces the supply of private capital available for investment in national growth objectives. To an undetermined extent (probably small), ${ }^{9}$ it also reduces incentives to work, likewise reducing the growth of the economy.

Not only do we need to make choices between objectives, we need also to decide

${ }^{8}$ See 2 Report of the Royal Commission on Taxation 77 (ig66) [hereinafter cited as Carter REport]; Eisenstein, Some Second Thoughts on Tax Ideologies, N.Y.U. 23D INST. ON FED. TAx. I, 3 (1965); R. Goode, The Individual Income Tax 312 (1964).

Incidentally, the Carter Report represents a sad but pertinent reflection of the way of the tax scholar. The Commission was appointed in I962. Over four years later it made a lengthy, complex report in six volumes, containing hundreds of conclusions and recommendations. Over twenty additional, and extensive, monographs were issued on special topies of interest. In 1969 the Canadian government issued a monograph entitled, Proposals for Tax Reform. Space does not permit analysis of this document. Essentially it proposed increases in exemptions, additional deductions for wage carners, limitation on tax benefits for mineral industries, some scattered proposals to "close loopholes," and a revision of the corporation tax that would be "fairer to small shareholders." Therc was also a proposal to tax capital gains. See Canadian Ministry of Finance, Proposals for 'Tax Reform (1969); Break, Integrating Corporate and Personal Income Taxes: The Carter Commission Proposals, in this symposium, p. 726. Somcwhere between the Commission and the government, the Olympian view was very sharply narrowed. Still less may be expected by the time the Canadian Parliament takes action.

'See notes 19, 20, \& 21 infra. 
what tax policy will accomplish the objective we have selected. If, for example, the objective is economic growth, we need to know whether we want growth on a broad or narrow front, and whether (for example) we should especially encourage investments in stocks as preferred to investments in real estate. Or assuming we want to support growth in commercial or residential real estate developments, we must consider whether we should move toward greater depreciation allowances or toward some other tax shelter for investors. And even when we decide what we want to do in terms of economic or social results, we do not always know how to do it. ${ }^{10}$ With this caveat, let us briefly examine the often restated goals of the tax structure, reflecting, as we proceed, on the diversity of attitudes concerning what the goals are and how best to reach them.

Simplicity. No one who has worked with the Internal Revenue Code and Regulations can deny that simplification of the tax law is and ought to be a primary objective in tax reform. ${ }^{11}$ It is equally clear, however, as Randolph Paul once suggested, that tax laws cannot be drafted "in the simple language of a pill advertisement." This is especially true where the law is intended to trace, through extremely complex transactions, the line between conduct which serves the tax objectives described hereinafter and conduct which does not so serve.

Equity. It is often said that in drafting tax statutes we must seek equity and fairness. ${ }^{13}$ Stated otherwise, it is emphasized that equity and fairness require that

\footnotetext{
${ }^{10}$ For a work devoted to an analysis of some of these difficulties, see J. SNEED, THE Configurations of Gross InCOME I-5 (1967); for a more specific comment, consider 2 CARTER Report I34, in which it is pointed out that

"Unfortunately there is no method of determining in a completely objective, and hence incontrovertible, way how well product and factor markets work or the precise impact of particular features of the tax system on the allocation of resources. Even if we knew the marginal value productivities of each resource, that is, the value of the output produced by the last additional unit of the resource used in each industry (and we do not), these data would be difficult to interpret because of possible imperfections in the market. ..."
}

For a further discussion, see notes $40-42$ infra and accompanying text.

11 This observation is often made. For examples, see U.S. Treasury Department, Tax Reform Studies and Proposals 73 (Comm. Print 1969); Stone, United States Tax Policy: Reflections on Changing Goals and New Hopes for Improvement, U. So. CAL. I966 TAX INST. I, I0-12; STAFf of Jornt Economic Comar., 88th Cong., 2d Sess., The Federal Tax System-Facts and Problemis, 35 (Comm. Print I964).

${ }^{10}$ Paul, Preface to First Edition, J. Stanley \& R. Kilcullen, The Federal Income Tax at vi (2d ed. x95ז).

${ }^{13}$ TAX Reford Studies, supra note $\mathrm{II}$, at 18-22, 37-38; Stone, supra note $\mathrm{II}$, at 7-10.

"We assign a higher priority to the objective of equity than to all the others. . . [O] ur task requires us to make recommendations that would lead to an equitable distribution of the burden of taxation. We are convinced that unless this objective is achieved to a high degree all other achievements are of little account. Thus the need for an equitable tax system has been our major concern and has guided us in all our deliberations."

2 Carter Report 17. See also Goode, supra note 8, at 312-I3; H. Simons, Federal Tax Reform 8-r2 (I950); Studies in Substanttve TAX Reform I7 (A. Willis ed. I969). The latter study was conducted under the auspices of the American Bar Association and the American Bar Foundation, and contains contributions by Dean Galvin, Mr. Willis, Mr. and Mrs. Ott, and Messrs. Bernstein, Tinney, Robbins, and Turner. 
taxes must be based on ability to pay. ${ }^{14}$ But when we compare equity and simplicity as objectives of taxation it is apparent that they must necessarily be inconsistent. No great profundity is required to conclude that if exact equity is to be brought to taxpayers caught in a multitude of various financial circumstances, reflecting a little more equity here or a little less there, complicated statutes are going to be required to draw the line between the deserving and the undeserving. ${ }^{15}$

Even a casual glance reveals that the objective of simplicity has suffered cruelly in the 1969 act. Such is the invariable result of attempts to stuff a finger into every hole in the dike. This does not, of course, mean that simple fairness can be disregarded; no single factor of tax policy has received more fervent accolades, ${ }^{10}$ though some have noted that our devotion to this objective is more apparent than real. ${ }^{17}$

It should be noted also that equity is an awkward objective in terms of tax incentives. For example, it may be thought desirable to give depreciation advantages to the builders of low-cost housing, as was proposed in 1967 in S. 2100 of the Ninetieth Congress (the so-called Kennedy-Smathers bill). ${ }^{18}$ Such a choice would mean that the person who builds housing in the ghetto pays less tax on his dollars earned than a person who, for example, builds factories, and equity necessarily suffers.

Still further, even where we are in fact dedicated to an objective of equity-as in the case of progressive taxes based on ability to pay-we may be misled. The income tax may be far less progressive than we thought at an earlier date, ${ }^{19}$ and progression may be somewhat less restrictive on growth than we had thought; it does not presently appear to restrict the efforts of executives. ${ }^{20}$ Moreover, progressivity does not seem to curtail work effort either by retarding the efforts of working wives or

\footnotetext{
${ }^{14}$ Goode, supra note 8, at 312, 313; Hambrick, The Illusion of Tax Reform, 1963 Duke L.J. 56, 58 et seq.

${ }^{15}$ See the sources cited in notes $8 \& \mathrm{I}_{3}$ supra. This difficulty was recognized (but minimized) by Professor Simons at an early date. Simons, supra note 13 , at 9.

${ }^{10}$ See sources cited in notes $13-15$ supra.

${ }^{17}$ See, e.g., Hambrick, stupra note 14 , at 74 , in which the author suggests that we really do not believe a lot of things that are said about equality, calling attention to

"our treatment of single persons and married persons, or single persons living alone and single persons who are heads of households, or single persons and surviving spouses, or young persons and old persons, or working people and retired people, or citizens who live here and citizens who live and work abroad, or blind people and people who can see, or sick people and healthy pcople, or sick young people and sick old people."

This was written in connection with the argument often heard that equal incomes should bear equal burdens.

${ }^{18}$ See Hearings on $S .2100$, supra note 5.

${ }^{19} I d$. at $63-64$; Goode, supra note 8 , at $3 I I$.

${ }^{20}$ See R. Barlow, H. Brazer \& J. Morgan, Economic Behavior of the Affluent 150 (I966), in which it was stated,

"Seven-eighths of the high-income respondents explicitly stated that they had not curtailed their work effort on account of the income tax. Many of the tax disincentives reported by the remaining respondents seemed implausible in the light of other information.

"On the basis of some simplifying assumptions, it appeared that the loss of annual output in the economy due to the existence of the progressive income tax instcad of some feasible alternative was extremely small."
} 
inducing an early retirement of male executives. ${ }^{21}$ And so the concept of equity, especially in relation to the concept of growth, needs constant re-examination. ${ }^{22}$ The same disparity between the easy assumption and the results shown by careful investigation may well appear as to other tax objectives.

Resource Allocation. In the preceding paragraph attention was drawn to the work effort of taxpayers. This is facet of an often reiterated objective of the tax structure: to control the allocation of personal and capital resources for the benefit of the national economy. Use of the tax structure to control resource allocation has also been emphasized in a different context. It has been suggested, for example, that where tax incentives create a narrow tax base so that tax rates have to be higher than would otherwise be necessary, the natural result is that more taxes will have to be paid by the generality of taxpayers. A tax shelter on one hand and a tax burden on the other, it has been said, "has the effect of driving labour and capital away from activities that are heavily taxed and drawing them into tax-favoured activities. Unless these pressures nicely compensate for non-tax distortions in the market, labour and capital are less productively important than they should be."23 It is of course true that in some instances-for example, with respect to oil and gas-resource allocation on the basis of tax statutes is indeed immediate and automatic. ${ }^{24}$ But here again generality is misleading and the easy rule is less than meaningful.

Fine Tuning. For some time it has been popular to suggest that the tax structure should be used in order to enable the nation to tread successfully the narrow line between inflation and deflation. A good many enthusiasts for fine tuning the economy by such devices as the surtax have recently had reason to doubt whether market demands react as quickly to these devices as some have asserted; the surtax has not been notoriously successful in taking the heat out of the economy. Even so, it seems clear that some (unmeasured and perhaps unmeasurable) relationship

\footnotetext{
21 Id. at I50. See also notes 36 \& 42-46 infra and accompanying text. But cf. J. RHrs-WriliaMs, Taxation and Incentive i7x et seq. (1953).

Consider a comparison of the equity and growth objectives in 6 CARTER REPORT 84 (x966):

"If equity were of no concern the most effective tax method of encouraging the labour force participation of wives would be to impose low marginal rates of tax at the bottom of the schedule, allow husbands and wives to choose not to aggregate their incomes, and allow families to deduct the special expenses incurred when wives work, or provide credits in lieu of these deductions. We are not prepared to recommend that Canada should go this far to encourage the participation of married women in the labour force."

${ }^{22}$ Of course equity works both ways. It has been suggested, for example, that a taxpayer who buys bonds relying on their tax-exempt features thereby creates equities in himself which should not be disregarded if the advantage is to be withdrawn. See Stone, supre note Ir.

For an extensive discussion of progression, see C. GaIVIN \& B. Birtrer, The Income Tax: How Progresstve Should It Be? ( 1969 ).

${ }^{28}$ I CARTER REPORT 24. This is a somewhat extreme and simplistic view of the relationship between the tax structure and the general supply-demand flow for capital and services in the market. The tax structure scarcely affects the allocation of resources as mechanically as suggested. For a somewhat more analytical study of the impact of the individual income tax on the growth of the economy in the United States and other nations, see V. TANZI, THE Indrvidual Income TAX AND Economic Growitr (xg69).

${ }^{21}$ See Stone, supra note II, at 3.
} 
between tax policy and the economic balance of the country does in fact exist. ${ }^{25}$ Certainly it is impossible to avoid the fact that, in fighting inflation, money should be in short supply. Tax increases are levied on lower income groups whose allocation of dollars to consumption is high. But any attempt to quantify the effect of attempts at fine tuning would certainly be premature. Many questions about this device have yet to be answered. ${ }^{26}$

Neutrality. Still another objective attributed to the tax laws is neutrality; they should be so structured that they will not produce an advantage for one of two similarly situated persons.

This is a doctrine which is not only most clearly observable in the breach ${ }^{27}$ but presents obvious difficulty. Let us merely note the problem of deciding when two parties are indeed similarly situated; this is not likely to be a fertile field for exploration. Let us also put aside for the moment the question of when neutrality should give way to some other objective. Let us instead consider the relationship of neutrality to the objective of economic growth.

It was observed, for example, in a Treasury Department report that neutrality of the tax system is a proper tax objective because it is generally undesirable for special provisions of the income tax to influence the outcome of economic decisions of taxpayers; otherwise investment resources are misallocated for tax savings. ${ }^{28}$ The same conclusion was reached in the Report of the Canadian Royal Commission on Taxation, in which it was suggested that in order to maximize the growth of input to the economic system the tax structure should be neutral; that is to say, it should be used to bring about a minimum effect on the allocation of resources within the private sector. This was based on the asserted principle that "the allocation of resources in response to free market forces will in general give in the short run the best utilization of resources, and in the long run the most satisfactory rate of increase in the output of the economy."20

However, there may be-and the whole idea of tax incentives is based upon this

\footnotetext{
${ }^{25}$ See, e.g., the observations in id. at 4-5, emphasizing that previous tax cuts stimulated the economy to the point where employment was increased. The Royal Commission on Taxation demonstrated what seems to the author in the hindsight of current inflation a misguided enthusiasm:

"After weighing the evidence and assessing the political as well as the economic problems involved in the use of stabilizing fiscal policy, we have reached the conclusion that changes in personal income tax rates or credits are beyond question the most effective single tool for discretionary stabilization policy. This does not mean that other tools can be discarded .... But, by and large, situations of deficient or excess demands that threaten to move the economy toward extreme unemployment or excessive rates of price increase should be countered primarily by changes in the personal income tax."

2 Carter Report 6o. See also SNeed, supra note ro, at I-5; Kurtz, Tax Incentives: Their Use and Mistuse, U. So. CaI. r968 TAx INst. I, 2.

${ }^{28}$ See Tax Changes for Short Run Stability, Hearings Before the Subcomm. on Fiscal Policy of the Joint Economic Comm., 8gth Cong., 2nd Sess. passim (1966).

${ }^{27}$ See note 17 supra.

${ }^{28}$ TAX REForM Studies, supra note $\mathrm{II}$, at 73.

${ }^{20} 2$ CARTER REPORT 8. See also note 23 supra and accompanying text.
} 
theory-an advantage in influencing the outcome of economic decisions to reach a socially desirable result. That is to say, one need not be wildly enthusiastic about tax incentives to understand that when a nation has a housing problem the deductibility of interest, taxes, and accelerated depreciation by an entrepreneur in slum housing is pertinent to filling a social need. The tax incentive may not be the best solution-this will appear in the future-but it is relevant.

The relationship of neutrality to growth should be considered in another context. Consider neutrality in the sense that a person who owns his own home with a mortgage gets to deduct his interest payments for income tax purposes while one who rents a house (on which the lessor-owner is deducting interest payments for income tax purposes) has no such deduction. This treatment is not neutral.

But it may not be easy to correct this unneutrality. ${ }^{30}$ An example is put in which an individual currently pays $\$ 1500$ per year interest on his mortgage and obtains $\$ 1500$ per year as interest from bonds. Under present law these items wash out; that is, he has an interest deduction for $\$ 1500$ and a like item of income from the bonds. Suppose the law were changed so that he could not deduct the interest paid with respect to the mortgage on his house; he would then have a net $\$ 1500$ in interest income arising from the bonds. In order to avoid that problem he might then cash in his bonds and pay off the mortgage. This would leave him with no interest with respect to the bonds. Neither would he have any interest deduction. In short, his net situation with respect to interest income and deductions would be the same following the change in the law as it was before: no net interest income and no net interest deduction.

In cases like these it is impossible to draft a tax statute to eliminate unneutrality because taxpayers may always be expected to distort normal business and personal transactions where distortion will (to their knowledge) result in tax advantages. ${ }^{31}$

Growth. The foregoing leads to further examination of the proposition that economic growth should be encouraged through tax statutes. Obeisance is frequently paid to this objective; ${ }^{32}$ however, a number of complexities arise when

\footnotetext{
${ }^{80}$ See Willis, Comments and Observations by the Project Director in Studies in Substantrve Tax REFORM, supra note 13 , at 20.

${ }^{32}$ Willis refers to these problems as related to "first order" effects of a change in the statute (the elimination of the interest deduction on the mortgage) and "second order" or "third order" effects which might arise from the efforts of the taxpayer to reduce his tax liability under the law as revised. Id. at 20-22. He also refers to the study by Robbins, Alternative Treatment of Corporate Income, in id. at 138 , in which Robbins discusses the taxation of capital gains at ordinary income rates, a change in the tax structure which would of course encourage corporations to declare dividends. It is pointed out that this would change taxpayer conduct by encouraging an enthusiasm for dividends rather than capital gains. Thus, a change in the law does not destroy the existence of a preference; it merely changes taxpayers' preference from capital gains to dividends; the change in the tax law will not necessarily lead to neutrality but to a change in preferences.

${ }^{32}$ See, e.g., SNEED, supra note ro, at I4 et seq. In 2 CARTER RePort II8, some interesting observations are made concerning the desirability of a comprehensive tax base as a means of encouraging growth. It is suggested that

"r. All tax systems have a number of anti-growth biases.
} 
attempts are made to use specific tax statutes for this purpose. Growth results in part from the willingness of persons to work and invest, and it is extremely difficult to measure the effect of a statute on motivation of the taxpayer. ${ }^{33}$ Moreover, the encouragement of growth is tied up with all kinds of product and market factors with respect to which it is impossible to segregate tax from other incentives. An illustration may be found in the relationship of growth objectives to allocation of resources, already considered earlier in this paper. ${ }^{34}$ On this subject it was concluded by the Royal Commission that

Even if we knew the marginal value productivities of each resource, that is, the value of the output produced by the last additional unit of the resource used in each industry (and we do not), these data would be difficult to interpret because of the possible imperfections in the market. For example, if those in command of some industries are able to control output and prices to some extent, the marginal value productivities of resources used in such industries is likely to be high, relative to other industries that do not have the same degree of market control. But tax incentives are unlikely to increase the flow of resources into these industries, and thus bring the marginal value productivities of labour and capital into line with those in other industries. The tax incentives will only raise the profits of the firms in the industry or the return to those who supply the factors of production. ${ }^{35}$

The difficulties of reaching hard conclusions about the best tax structure to increase growth are multiplied (as will be noted later with respect to tax incentives) by unsolved issues concerning how the tax structure motivates people. For example, it is often suggested that high tax rates tend to lower productivity. On this subject it has been observed,

The degree to which progression tends to lower productivity is inherently difficult to gauge. For the most part it would appear to depend upon the effect which progression has upon the motivations of man, and most of what can be said on

2. Capital markets work imperfectly in some areas and thereby create anti-growth biases.

3. The taxation of income, comprehensively defined, at relatively low marginal rates, will distort the allocation of resources less, and hence reduce the rate of growth less, than a narrow tax base taxed at higher rates.

4. Some of the anti-growth biases can be compensated for within the tax system without foregoing a basically equitable system.

5. Reforming the tax base and rate structure should therefore not reduce the rate of growth and may increase it.

6. Maintaining full employment will increase the growth rate significantly.

7. If a higher growth rate is desired this will necessarily involve some sacrifice of present consumption, or leisure, or an increased reliance on foreign saving. Tax measures designed to provide additional stimulus to saving and investment may be adopted as part of growth policy, but these will involve some reduction in the overall equity of the system."

No doubt the foregoing observations represent satisfactory economics; the extent to which such comments may be significantly used in the formulation of tax policy is still by no means clear.

${ }^{88}$ See the observations on this subejct in TAX REFORM STUDIEs, stipra note II, at 30-3r. See also notes I9-2I supra \& 43-46 infra and accompanying text.

see notes 23-25 supro and accompanying text.

${ }^{85} 2$ Carter Report I34. 
either side is in the realm of conjecture in psychology and is likely to remain there..$^{38}$

Beyond all of this there is an additional problem in pursuing the tax objective of economic growth: if we increase capital investment and the labor pool too much, the supply of goods may outrun demand unless the economy is governmentally managed in far more significant ways than through the tax structure. If this happens and demand declines, growth may be expected to slow down, perhaps to the point that consumption needs to be stimulated at the expense of growth. This raises the question previously noted: whether such fine tuning through the tax structure can be effective. Certainly the effect of government spending may be a much more significant factor than tax incentives.

Growth of the economy is a fine ideal, but we are far from knowing how to attain it through the tax structure. Still less can we evaluate its importance compared with other objectives of the tax structure and nontax means of obtaining ideal growth.

Summary. The fact most apparent from the foregoing is that we have created a mythology about tax objectives; the public has not critically evaluated them. Properly understood, they serve only to cloak a general and unspecific attitude about factors which may in some degree, in one way or another, properly come into a decision about whether a specific statute should be enacted. There is an analogy to the rule in tort cases that one must act as a reasonable man. In each case, application of a principle to specific facts is essentially intuitive.

To change the approach, let us also remember that even if we were able to establish a rational schedule of internally consistent objectives for the tax structure, the objectives themselves may be inconsistent with one another. Congress in considering a specific item of legislation might reflect upon the relation that it bears in terms of equity to the objective of growth; after measuring the primary effect of the legislation on growth it might consider how the effect on growth is reflected in the quantum of simplicity; after evaluating these components Congress might thereafter consider the effect of the statute on the factor of neutrality, thereafter considering how in the light of all the foregoing factors the proposed statute would operate in terms of proper allocation of national resources or fine tuning of the economy.

Numerous similes come to mind; the introduction of any new statute (or the withdrawal of an old statute) from the tax structure may be likened to throwing a pebble into a pool. Every objective of the tax structure is affected in some degree. The problems are so complex, and the state of knowledge in which we seek to understand them is so confined, that we may well despair of reaching an informed conclusion. This does not mean that we cannot or should not make a rough guess; it

\footnotetext{
${ }^{80}$ Blum \& Kalven, The Uneasy Case for Progressive Taxation, Ig U. CHr. L. Rev. 4I7, 437 (I952). See also notes I9-2I \& 33 supra \& 43-46 infra and accompanying text.
} 
may mean that, unless we can make more than a rough guess about the effects of such a course, we should not pile on additional members of the tax structure so as to encourage desirable behavior. In short, it may indeed be unwise to flee to evils of which we know not.

In any case it is time to examine the place that tax objectives play in the adoption of tax legislation generally, including tax incentives.

\section{III}

\section{Are Tax Objectives Measured Against Tax Legislation?}

It will come as a surprise to no one that discussion of the objectives of taxation is usually found among academicians and study groups. There can be no explanation for a tax structure as sprawling and inconsistent as that which we have at present, except that it has been created by intensely practical people more concerned with the immediate result than the eternal verities. Even a very comprehensive study of the federal tax system, made by the Treasury Department for a joint committee of Congress, fails to measure specific members of the tax structure against the ideal objectives of the taxing system. ${ }^{37}$ A casual study of the congressional committee reports over recent years reflects information about what a bill does but not about why the bill does it.

There was some improvement in the committee reports respecting the Tax Reform Act of $1969 .{ }^{38}$ There the discussion of important provisions was introduced by a statement of present law, followed by general reasons for a change and an explanation of the provisions. In substantially all cases, however, the reasons listed for a change were only based on asserted considerations of fairness in the application of the tax laws. Other objectives of the tax structure were either not considered or, if considered, were unstated. Though tax objectives are couched in general terms, their consistent use as guidelines would give some elements of form to a legislative process now painfully haphazard. It should be noted at once that Congress must be required to bear only a moderate portion of the responsibility for failure to state the reasons for a law. Administrators and the courts are charged with deciding what disposition shall be made of specific cases coming before them; rules are adopted by administrators interpreting statutes; their decisions are equally obscure in terms of reliance on accepted objectives of the tax structure. ${ }^{39}$

\footnotetext{
${ }^{37}$ TAX Reford STUdies, supra note Ir.

${ }^{38}$ H.R. Rep. No. 91-413, 91st Cong., rst Sess. (1969); S. Rep. No. 91-552, 91st Cong., Ist Sess. (1969).

${ }^{30}$ At the risk of being (accurately) accused of intellectual incest I should like to quote the following on this subject:

"Those who make our laws and those who interpret them by regulation, ruling, and decision must be courageous enough to acknowledge and defend the factors which motivate their policy decisions. When a pattern for this conduct is established, a long step forward will be taken toward bringing our tax structure back to a realistic, fair and logical adjustment of the burden of each citizen to support his government. It must now be clear that this result can never be
} 


\section{Some Specific Criticisms of Tax Incentives}

$U_{p}$ to this point we have noted that there are no really understandable and finite objectives of the tax structure against which tax incentives can be measured. It is likewise clear that Congress has not in fact (at least so far as the committee reports reveal) sought to balance objectives in measuring tax legislation, including legislation respecting incentives. Let us turn now toward other criticisms-some new, some traditional - of the use of incentives. It will be noted at once that many of these overlap.

Prediction of the Consequences of Tax Incentives. It is very difficult to predict the effect of tax incentives. The initial hurdle in deciding to examine the way in which a tax incentive has been operating is the apparent unwillingness of Congress to make a serious investigation into the subject. Moreover, notwithstanding that economic science has been regarded as affording precise and measured answers (as compared to the intuitive responses reached by lawyers), there seems to be a justifiable suspicion that economists cannot by econometrics answer such questions as these. Whether the scholar works through the disciplines of the lawyer or the economist, it must be conceded that the state of the art of measurement is not advanced. ${ }^{40}$

The results of any empirical study with an economic model are necessarily somewhat dubious unless a study is made in which all the factors in the experiment are

reached by piling palliative upon palliative, long retreats upon short advances, and the traditional

silence respecting basic policy decisions of all branches of government controlling the day-to-day adjustment of our taxing statutes."

Rice, The New Tax Policy on Deferred Compensation, 59 Mrcr. L. Rev. $38 \mathrm{r}, 40 \mathrm{r}-02$ (196r).

${ }^{\circ 0}$ Kalven, The Quest for the Middle Range: Empirical lnquiry and Legal Policy, in LAw IN A CFanging Asrerica 56, 67 (Hazard ed. ig68):

"Robert Merton some years ago observed that in their current state the social sciences could aspire only to theories in the middle range. We can adapt his remark to the application of social science to legal problems: it can only aspire to facts in the middle range. Some premises are too deeply held for actual footnoting, and some facts are too well and accessibly known for professional inquiry. What remains then as the critical area is the middle range where the premises are not that unshakeable and where the facts are not that accessible."

An example which comes to mind is found in the attempts of the Royal Commission on Taxation to ascertain the manner in which the tax structure affects national growth. In 2 CARTER REPORT II8, the subject of fiscal policy for growth was considered and an attempt was made to measure the relative importance of different factors in growth. This required, of course, that the element of migration be considered. Here a primary difficulty arose from the problem of ascertaining why people migrated from Canada to foreign countries; motivation is notoriously difficult to measure, as noted in the text accompanying notes $43-46$ infra.

In addition, the study is based on the extent to which additional manhours will arise from the increased or decreased willingness of the population to work. Any conclusion on this subject is necessarily speculative, again in large part because of the element of motivation. Moreover it must be recognized that so far as the younger work force is concerned, it is not the existence of taxes but the presence of opportunity for education that takes people out of the work force. Another element which can hardly be measured in terms of motivation is the desire of females to work. When there are all these imponderables, it is not easy to segregate out the issue of taxes and examine and quantify the effect of the tax structure upon the number of persons participating as members of the labor force. 
constant with the exception of the item which is to be tested. Anyone familiar with calculus will recognize this search for the nature and quantum of the variable. To put the matter in primitive language, if there are five variables it is extremely difficult to tell whether a different result between two control groups is attributable solely to one of them or to determine in what proportions it is attributable to each of the five. The possibility of profitable analysis of these issues has been carefully explored in a study of the incidence of the federal corporation income tax, in which the approach to the subject was considered in terms of an organization chart with lines connecting boxes expressing different variables. The prognosis was not encouraging. ${ }^{41}$

Finally, we know far too little about the actual results of tax incentives assumed to encourage socially desirable conduct. Indeed, prediction here is so difficult that it has been argued that a high depreciation allowance to landlords may be counterproductive in efforts to rehabilitate slum areas. The suggestion is made that high depreciation merely induces landlords to sell the property after a few years rather than repair it. ${ }^{42}$

An additional problem should be recalled. It is difficult to forecast the secondary effect of an incentive; assuming that one form of conduct is discouraged or en-

\footnotetext{
${ }^{41}$ See Klein, The Incidence of the Corporation Income Tax: A Lawyer's View of a Problem in Economics, 1965 Wisc. L. REv. 576, 588:

"The separate boxes in the chart would be used to represent separate bits of information about individual and firm behavior, while the lines between the boxes would represent the effect of each element on all others. The process of analysis of the incidence problem may then be perceived in terms of altering the contents of one box, that containing corporate tax revenues, and then figuring out from the chart how other elements of the economy will be affected, how these will in turn affect still other elements, the "feedback" of these changes on the tax variable and other variables previously considered, and so forth until a new resting place, or equilibrium position, is found. The new position is then compared with the old and the effects of the tax become apparent.

"There are several basic and perhaps insurmountable difficulties with this kind of approach as applied to the study of a variable as complex and pervasive in its ramifications as a tax change. First, the information needed for each box is often not available. For example, it may not be known on what terms labor and capital may be substituted for one another in a given sector of the economy. Second, the relationships between the vast number of boxes are largely unknown and are so complex as to be largely beyond the grasp of the human mind. For example, what is the effect of a change in prices in one sector of the economy on the demand for products in another sector, how will this affect employment in each sector, how will this in turn affect total demand, and how will this then affect the prices charged and the employment available? And finally, in the real world other elements will be changing at the same time that the process of working out the effect of the tax change is taking place."

The author ultimately sought to answer questions about the tax incidence in terms not of what should happen, in terms of econometric analysis, but what actually did happen as reflected by such facts as were available.

"Sporn, Some Contributions of the Income Tax Law to the Growth and Prevalence of Slums, 59 CoLtu. L. Rev. 1026, 1037-1047 (1959). A reply to this article is found in Blum \& Dunham, stupra note 5. There is every reason to believe, incidentally, that CODE $\$ 1250$, requiring sellers of real estate to report as ordinary income certain recaptures of depreciation allowances arising from the sale of real estate previously depreciated, has not affected the turnover rate in slums. See Schering, Depreciation Deduction on Used Residential Housing: Turnover Rates in Slum Housing Ownership, and the Tax Reform Act, 38 Cinn. L. Rev. 539 ( 1969 ).
} 
couraged by an incentive, it is even more difficult to know what the secondary or tertiary effects of that encouragement will be as taxpayers make adjustments to the initial effect. ${ }^{43}$

Another difficulty in measurement is found in the so-called multiplier effect of tax incentives; an incentive for building in the ghetto, for example, may be thought to be of advantage not only in providing better housing in the slums but also in providing employment. Similarly, in trying to ascertain the cost of a tax incentive, it is sometimes argued that the incentive will cost little or nothing because it will encourage activity resulting in increases in taxable income throughout the taxpayer community. It goes without saying that these amounts are extremely difficult to estimate because of the many variables involved.

Indeed, in some models assumptions are piled on supposition and presumption on conjecture. Even where field work is undertaken it is not always possible to conduct a study under sufficiently controlled conditions so that a difference in the attitude of one investigator from another will not on that account lead to different results.

Motivation. The basic premise of tax incentives is that persons will be motivated by the incentive to pursue a desirable course of action which they might otherwise reject. Some difficulties with this concept with respect to a motivation to work and invest have already been noted. ${ }^{44}$ Other illustrations abound; for example, from a survey conducted among approximately one thousand individuals having incomes of $\$ 10,000$ or more it was concluded that "the awareness of preferential tax treatment and the inclination to take advantage of it appeared to be confined to a small minority of high-income people, with the notable exception of the tax advantages of capital gains." ${ }^{\text {45 }}$ However, there can be no doubt that an indeterminate quantum of motivation toward tax avoidance exists; there is no other way to explain the

\footnotetext{
'3 See Studies in Substantrve Tax Refora, supra note 13. Notwithstanding this factor the approach to the solution of future tax policy problems through econometrics and computer science is, in this work, optimistic.

"See notes 16-19 supra and accompanying text. See also Blum \& Kalven, supra note 36, at 437-38:

"Progression basically may impinge on the productivity of the society either by reducing the amount or quality of work put forth or by impeding the creation or maintenance of capital in the society. The analysis therefore must be concerned with motivations to work and with the various motivations responsible for the creation and preservation of capital."

¿5 BarLow, Brazer \& Morgan, stipra note 20, at I7I. The conclusions of this study are stated as follows:

"It is clear that there are many more powerful motives affecting the working behavior of highincome people than the marginal income tax rates. People are aware of taxes and do not enjoy paying them but other considerations are far more important to them in deciding how long to work.

"As for investment decisions, it appears that high-income people tend to make their own decisions, often without seeking detailed information and understanding. Sensitivity to taxes appears in only two places: where income can be received in the form of capital gains and where it is possible to transfer assets to relatives and reduce one's tax liabilities by so doing.

"Only a very small fraction of the high-income population is making use of the other special provisions in the tax law. This means that these provisions are inequitable not only as between
} 
circumstance that progressive rates of the tax are not really effective with respect to persons of great wealth. ${ }^{46}$

Dubious motivation by tax incentives is illustrated elsewhere. Some steps have been taken to measure the extent to which a deduction for a charitable contribution encourages gifts by taxpayers to worthy causes, through use of econometrics and a statistical study. The results, while not as firm as might be hoped, indicate that the deduction is considered important in very few cases where the recipient is a religious institution; it seems to be important only with respect to people having in excess of $\$ 100,000$ adjusted gross income in other cases. ${ }^{47}$

Closely allied to problems in measuring motivation is a more general reflection upon the humanistic nature of law. It has been pointed out that law deals with a texture of government that continually changes, and that studies about the law necessarily deal with value judgments about social problems. ${ }^{48}$ Of course, data available through such activities as the Brookings project will assist in making measurable some of the effects of tax statutes. We may not be able to determine what has motivated taxpayer conduct, but we will at least be able to ascertain what the taxpayer conduct has in fact been. Recent attempts to measure such conduct have been encouraging, ${ }^{49}$ though much remains to be done.

Uncertainty in Use of Tax Incentives. Another problem in evaluating tax incentives is that the needs of an individual taxpayer who may or may not desire to avail himself of the tax advantage cannot be foreseen in advance. In S. 2100 in the Ninetieth Congress, a tax advantage in the form of extra depreciation allowable to persons building low-cost housing was proposed. Mr. Barr, then Undersecretary of the Treasury, questioned the desirability of this incentive:

It becomes a matter of careful calculation for each investor, and his tax adviser, to determine how much this extra depreciation is worth in the particular case and

high-income and low-income people but also within the high-income group. Their modification would adversely affect fewer people than some have thought." Id. at 7 .

${ }^{6}$ See the discussion of this subject in Caplin, The Minimum Income Tax and Related Reforms, 55 VA. L. Rev. 840 et seq. ( 1969 ). For a criticism of the assumption that taxpayers, when asked, do in fact reveal the extent to which tax savings control transactions, see Klein, note $4 \mathrm{I}$ stupra, at 590 et seg. Thus it should not be assumed that the conclusions in the Barlow study in the preceding note are beyond attack.

${ }^{47}$ Taussig, Economic Aspects of the Personal Income Tax Treatment of Charitable Corporations, 20 NAT'L TAx J. I ( 1967 ). The data as to contributions was taken from the so-called Brookings file of 1962, which included 103,386 individual income tax returns which were computerized; information with respect to contributions was included.

The conclusion was also based in part upon reference to more general factors. For example, it was found that the changes in the rate of giving for the calendar year 1964 did not reflect any changes in tax laws that year but continued the long-time trend: the percentage of giving was found to have decreased from $4.09 \%$ to $3.91 \%$ and the total number of dollars contributed (because of increased dollar income) advanced slightly.

${ }^{* 3}$ See Kalven, supra note 40 , at 69, where the author, in noting the limitations on methodology, states, "There are two chief difficulties-the inability of social science to rely on the controlled experiment, and the difficulties of obtaining access to data when a living institution is the subject of study."

${ }^{\circ}$ For example, by Taussig, supra note 46 , and in Studies in Substantive Tax Rerond, silpra note I3. 
whether or not this justifies accepting a lower before-tax return. It may be useful to point to the analogous situation of tax-exempt bonds. One cannot answer the general question: "Are municipals a better investment than U.S. Governments?" without examining, and making assumptions, about the future total income prospects of the investor. The value of the tax exemption depends upon future tax rates. It is well known that tax-exempt bonds are attractive investments to high-income taxpayers but not to low-income taxpayers. It is also suggested in the literature on the tax exemption that this constitutes a rather inefficient incentive because the net incentive effect must work through the marginal investor who will get less advantage from the exemption than higher bracket investors, and some of the benefit afforded the high-bracket investor is wasted. ${ }^{50}$

It is not possible to predict in advance whether the incentive will appeal to just the right category of taxpayer. In any case, the fact that we cannot predict who will use the incentive makes it difficult to weigh the advantages and disadvantages of using it at all.

Control. There is a series of less complex reasons to be urged against the use of tax incentives. Once a tax incentive is granted, it continues year by year without examination or control. It has been noted that a direct grant, on the other hand, is reviewable annually in the course of the budget process so that the beneficiaries of the grant must continually explain and defend their need for public support and must compete for that support annually with other worthy projects. So it is suggested that direct grants should be favorably considered as an alternative to tax exemptions. ${ }^{51}$

Alternatives to Tax Incentives. Evaluation of tax incentives should not be undertaken without a careful consideration of alternatives other than direct grants. Leaving to one side the question whether a specific tax incentive is really adapted to the promotion of desirable conduct ${ }^{52}$ and whether a tax subsidy will in fact accomplish the results sought in a particular case, ${ }^{53}$ there is also a question whether the subsidy is best adapted to the purpose sought. ${ }^{54}$ Examples could be multiplied. During the hearings on S. 2100, Secretary Weaver called attention to the circumstance that the proposed bill was less suitable to alleviating problems of low-cost

\footnotetext{
${ }^{50}$ Hearings on $S .2100$, supra note 5 , at 143.

51 As, for example, in the instances discussed in Kurtz, supra note 25, at 21-22. For a comprehensive discussion of the subject see Surrey, Tax Incentives as a Device for Implementing Government Policy: $A$ Comparison with Direct Government Expenditures, 83 Harv. L. Rev. 705 (1970). See also notes 54-60 infra and accompanying text.

${ }^{23}$ See, e.g., the observations in note 42 supra and accompanying text.

${ }^{63}$ As discussed in the colloquy between Senator Kennedy and Secretary Weaver of Housing and Urban Development in Hearings on $S .2100$, supra note 5 , at 132 et seq.

Es Thus, in the hearings with respect to $S$. 2100 , then existing approaches based on government guarantee of loans and low interest rates were said by Secretary Weaver to be less costly than the proposed bill which incorporated these proposals and in addition provided for tax incentives. Id. at 129. See also id. at $134-35$ for his comments on rent supplements. Of course, the difficulty of predicting the effect of a tax incentive (see notes 40-4I supra and accompanying text) makes dubious any decision about whether a direct subsidy or a tax subsidy is the best solution to a social or economic problem.
} 
housing. than rent supplements. ${ }^{55}$ Money is not saved; as Undersecretary Barr observed during the hearings on S. 2I00, in comparing tax incentives with direct grants, "Each is a buck."

A brief reference to some of the alternatives to tax incentives will be sufficient. Commentators have preferred direct grants to tax incentives where the objective was increased mineral exploration, ${ }^{57}$ encouragement of contributions to political campaigns, ${ }^{58}$ encouragement of business to locate in specific places, ${ }^{50}$ and expenditures for research and development. ${ }^{60}$

In connection with the general subject of tax reform, Henry Fowler, when Secretary of the Treasury, observed that other alternatives to tax incentives long have existed, and cited devices familiar to all: guaranteed loans, equal opportunity grants and other programs to aid in retiring the costs of higher education, similar grants for pollution control, interest subsidies to alleviate the strains found with respect to housing for the poor, and government contracts with private employers to train the otherwise unemployable. ${ }^{61}$ Similar vigorous attacks on the use of tax incentives have been made by Undersecretary Barr, who particularly emphasized use of interest subsidies, direct grants and rent supplements. ${ }^{62}$

\footnotetext{
${ }^{50}$ Hearings on S. 2roo, supra note 5 at 134-35. See also Kurtz, stpra note 25, at 13.

${ }^{56}$ Hearings on $S .2100$, supra note 5 , at 142 .

57 Carter Report i35 (1966).

${ }^{58}$ Kurtz, supra note 25 , at $9-13$.

${ }^{20} 2$ Carter Report i75 (1966).

${ }^{80}$ Id. at $\mathrm{r7} 6$. See also Surrey, supra note $5 \mathrm{I}$.

${ }^{61}$ See the following statement of Secretary of the Treasury Henry Fowler, in TAx REForm Studies, supra note $\mathrm{II}$, at $7-8$.

"In working on the structure of our tax system, one is confronted with the suggestions for tax incentives to enlist private initiative to meet our social and economic problems. We have given careful consideration in this proposed revision of our tax system to such possible solutions to these problems. We believe that our social and economic needs can better be served through direct measures outside the tax system, rather than by tax credits and other forms of tax incentives. Consistent with this conclusion, we have also attempted to minimize distortions caused by cxisting special tax provisions.

"Indeed, it has been our experience that when the proposed tax incentives are viewed as alternatives to budget expenditures, there are direct nontax methods available which are feasible and helpful, and which give greater benefits for the budgetary costs involved than do the tax incentives. Examples of effective nontax methods of achieving objectives that had been sought through the tax system include guaranteed loans, equal opportunity grants, and other programs to assist students and their families with the costs of higher education; direct grants for water pollution control projects; rent supplements and interest subsidies to increase the supply of lowand middle-income housing; and Government contracts with private employers to train hard-core unemployed for jobs. These methods achieve the important objectives in a manner consistent both with an equitable tax system and with careful and responsible budgetary control by the executive and the Congress."

${ }^{82}$ See the following testimony of Undersecretary Barr on S. 2100:

"I shall address myself later to the question of whether there are differences from the investor's standpoint or the Government's standpoint between dollars that are 'paid' as tax reductions and dollars that are 'paid' in other ways. It is useful first, however, to recognize the basic similarity between a dollar benefit received from tax savings and a dollar benefit from direct Government outlays. . . .

"A tax saving can always be reproduced by some form of Government payment program. $A$ tax credit of to percent of an investment provides the same result as giving an investor to
} 
Tax Incentives May Help the Wrong Person. A principal deficiency of tax incentives has been noted: it is difficult to draft an incentive so that it appeals to taxpayers in the middle rate area. The likelihood is that the incentive will appeal primarily to persons in very high income tax brackets. This seems clear because there is little inducement for a taxpayer in the middle bracket to risk his money in a speculation where the tax benefit to him will amount to relatively little; such an

percent of the cost of his investment. Allowing a taxpayer to speed up depreciation deductions by taking, say, 20 percent of the cost in the first year permits a corporate taxpayer to reduce its tax payment by 48 percent of this deduction in the first year, and it increases the tax payments at some future time when the deduction would otherwise have been taken. This benefit can be reproduced by offering the taxpayer an interest-free loan equal to the amount of tax saving from the rapid depreciation to be repaid in the future when he would have otherwise taken the depreciation.

"I cannot stress this point too strongly. There is no magic which permits Government to give away tax dollars and have a lesser budget impact than if it had given away expenditure dollars, nor does a dollar of net budget cost have a different impact on the investor's after-tax rate of return if it is incurred as tax reduction or as direct outlay.

....

"For illustration, one may want to think of a tax incentive which provides an aninual tax credit for low-income housing investment exactly equal to the benefit that the investor would gain from an annual direct payment, which we might call a rent supplement. This hypothetical tax credit could be made available under exactly the same terms that rent supplements are made available under present law. The question comes down to: "What are the advantages or disadvantages of building this rent supplement program into the tax law?" "

Hearings on S. 2100, supra note 5, at $\mathrm{r}_{42}$. Other criticisms were made:

"[T] $T$ he tax route does not provide assistance to the individual or corporation which has limited income from other sources and which therefore cannot make full use of the tax incentives. A system of direct payments on the other hand could provide benefits even where the particular housing investment was the only activity of the investor being benefited.

"One would think that this was a general disadvantage of providing incentives through the tax system. The supporters of S. 2IOO, however, apparently believe that it is the large businesses which ought to be attracted into the low-income housing field and that they take it as no disadvantage to their tax approach that the benefits are only helpful to taxpayers with incomes from other sources. This I might add is not a particular advantage of the tax approach since this sort of condition could be built into the rent supplement program if we agree that the condition is a desirable one.

"Another difference between the tax and expenditure routes is that the tax benefits, where they are related to increased deductions, vary in amount according to the effective tax rate of the taxpayer. The tax benefit of rapid depreciation can be as high as 70 percent for the individual taxpayer in the top bracket or as low as I4 percent for a low-income investor. S. 2roo does provide some tax benefits that work through extra deductions, so that it will thus afford different relief for different taxpayers.

"It becomes a matter of careful calculation for each investor, and his tax adviser, to determine how much this extra depreciation is worth in the particular case and whether or not this justifies accepting a lower before-tax return. It may be useful to point to the analogous situation of tax-exempt bonds. One cannot answer the general question: 'Are municipals a better investment than U.S. Governments?' Without examining, and making assumptions, about the future total income prospects of the investor. The value of the tax exemption depends upon future tax rates. It is well-known that tax-exempt bonds are attractive investments to high-income taxpayers but not to low-income taxpayers. It is also suggested in the literature on the tax exemption that this constitutes a rather inefficient incentive because the net incentive effect must work through the marginal investor who will get less advantage from the exemption than higher bracket investors, and some of the benefit afforded the high-bracket investor is 'wasted."

Id. at $142-43$. 
advantage will be sought rather by the high-income taxpayer to whom the savings are more important. ${ }^{63}$ Moreover, the project must appeal to the entrepreneur with risk capital; it may be thought anomalous to convey this bounty on him in order to benefit the poor. Senator Williams made the following observations with respect to $\mathrm{S} .2100$ :

I will say the bill as it was, as it was pointed out, would be one of the greatest bonanzas that had ever been passed. Rather than a bill to take care of the povertystricken individuals, this would really be labeled more or less the poverty bill for the multi-millionaires. ${ }^{34}$

Concealment. There can be no doubt that governmental bounty intended to induce appropriate social action is effectively concealed from the public through the medium of a tax incentive. As might be expected, the use of tax incentives accordingly has been deplored because as a matter of equity, democracy, and general fair dealing there should be "minimal concealment and fullest exposure of his actual dollar burdens to every individual."65

Relation to Comprehensive Tax Base. Much has been said recently about the comprehensive tax base. ${ }^{68} \mathrm{~A}$ substantial body of commentators recommend the elimination of tax shelters of all kinds, including tax incentives, in order that general rates for the taxpaying public may be lowered. To the extent that Congress created new shelters in the Tax Reform Act of 1969 , these proposals were rejected, though the act destroyed other tax shelters on a piecemeal basis. Closely allied to the other arguments for a comprehensive tax base is the argument that the current tax laws are far too complex; from this, the flattering conclusion follows that in terms of allocation of national resources, we are spending far too much time of the best intellects in the country planning how to avoid the complexities of the current statutes. The difficulties currently encountered have been multiplied in the past and will be compounded in the future each time a new tax incentive finds its way into the tax structure.

The Cost of Tax Incentives. Among the many imponderables in deciding whether a specific tax incentive is desirable is the circumstance that the cost of the incentive can scarcely be predicted. Consider the quite complicated legislation proposed in S. 2100. There it was clearly impossible to predict the financial cost of the bill because it was impossible to forecast who would seize its advantages and what rates would otherwise be applicable to the income received tax-free as an incentive. Nor could estimates be made of the leverage which taxpayers would use in loans made available under the statute, leverage being directly referable to depreciation benefits for each dollar invested by the taxpayer. Where it is im-

\footnotetext{
${ }^{03}$ As suggested in note 49 supra.

${ }^{64}$ Hearings on $S .2100$, supra note 5 , at 157.

${ }^{65}$ Simons, supra note 13 , at 7 (1950). Almost every critic of tax incentives notes this factor.

${ }^{\circ a}$ For an illustrative discussion, see B. Brttrer, C. Galvin, R. Musgrave \& J. Pechman, A CompreHENSIVE INCOME TAX BAsE? (rg68), and sources cited therein.
} 
possible to estimate the cost of a project, there is an understandable suspicion that the incentive may cost too much. ${ }^{67}$

Incentives Hard To Terminate. It is evident that when a tax incentive is buried in the intricacies of the Internal Revenue Code, it is likely to be shielded from public attention. If there is no public attention, it is unilikely (even though there may be no justification for its continuance) that its shortcomings will be brought to mind. This being the case, it is probable that no attempt will be made to remove it. It is even more unlikely that a successful attempt will be made, particularly if a segment of the taxpaying public develops a vested interest in a certain provision, whether or not it discriminates against the generality of taxpayers. Continued attrition with respect to the original attempts to eliminate tax shelters from the tax structure as evidenced by adoption of the Tax Reform Act of $x 969$ bears ample testimony to this conclusion. Contests are seldom equal between a general public vaguely troubled by a possible tax inequity, and a vigorous pressure group seeking to protect its interests.

Tax Incentives and the Free Ride. Another criticism of tax incentives is implicit in much that has been said, but needs to be plainly restated. It is that very often people are given tax advantages to do something socially desirable which they would have done even in the absence of an incentive. That is, few will go into slum housing unless there is the expectation of making a net profit; the tax incentive is only one element in the decision, and in some cases only increases the desirability of a course of conduct which would be pursued in any case. Whether the entrepreneur gets a tax incentive or some direct subsidy, the inducement is wasted if he would have gone forward either without a subsidy of any kind or with a lesser inducement. As between the direct payment and the tax subsidy, it may well be possible to measure more accurately the necessary inducement through a direct payment rather than through a tax incentive.

Tax Incentives and Government Operations. One of the adverse side effects of tax incentives is that-as in the case of S. 2roo-an attempt is sometimes made to put the burden on the Treasury Department to police the operation which culminates in a tax exemption. Thus many more avenues of power would be open to that department with respect to matters outside its expertise and proper scope. Needless to say, this prospect has not been greeted with enthusiasm by the Treasury. ${ }^{68}$

Tax Incentives and Self-Deception. Lastly, there is in many cases a real temptation for legislators to adopt a tax incentive to demonstrate that they are interested

\footnotetext{
${ }^{07}$ In the case of S. 2100, Senator Williams suggested as much. Hearings on S. 2100, supra note 5, at $15 \mathrm{x}-58$.

${ }^{88}$ See the following testimony of Undersecretary Barr, id. at 144:

"I cannot help but observe that if we go along this tax incentive route the Treasury Department would soon be making the crucial decisions in almost all matters of domestic economic policy. This would, of course, require a larger staff; and it has enormous possibilities for empire building. We would, however, prefer to decline this honor."
} 
in some basic and perhaps unsolvable problem affecting the body politic. A tax credit or deduction for parents sending their children to college is a case in point. An incentive of this kind is only a drop in the bucket when one seeks a solution to the entire problem of adequate education for all. In any case, this provision is peculiarly useless to the underprivileged who do not pay taxes. A vote for such a bill reflects a concern for a proper object of federal support, yet those needing help most might find the project a delusion in practice. Another example is found in S. 2100, which sought to encourage housing construction in urban areas but was not directed to the poorest segment of the population and, in addition, was quite limited with respect to the number of housing units which could be encompassed by it. Such proposals may have undertones more political than social. The nibble at the fringes of the problem may in fact delay a serious attempt to solve it.

\section{$\mathrm{V}$}

\section{The Value of Tax Incentives}

To this point, substantially all of the comments have led to a conclusion that, on the whole, tax incentives are distinctly undesirable. If this were as patent as has been made to appear and if we are to accept (as we should) that members of Congress are neither stupid nor venal, we should consider why tax incentives appear in the tax structure and why new proposals for them are made periodically. Here again it seems worthwhile to emphasize the obvious. Let us make explicit that which few would dispute: tax incentives do not arise from economics but from politics. Vigorous pressures may be brought against the members of Congress with respect to the appropriation of funds for such items as rent supplements and dollar housing subsidies. Those who decry tax incentives must face the fact that the voting public is not always responsive to often substantial moral obligations of the government to provide benefits which are in the long-term interest of all: jobs, decent living conditions, and especially equal educational opportunities. It is not enough to describe tax incentives as a means of "seeking a backdoor expenditure where it is harder for people to see just what are the costs and benefits involved in the expenditure." ${ }^{\text {"8 }}$ If other approaches fail, social and economic needs thought to be paramount may justify the use of tax incentives, however inadequate, as a last resort.

A further and even less palatable observation might also be made. It is entirely possible that many who violently object to the theory of tax incentives are opposed principally to the extension of governmental benefits of any kind to the persons who are to be the recipients of the government's bounty. The real (and unanswerable) question is this: Can the response of all the people and their government to the needs of the few be so swift and sure that the subterfuge of tax incentives can be abandoned?

\footnotetext{
${ }^{60}$ Id. at I 45 .
} 
Whatever else may be said about the tax incentives, they do give democracy some play in the joints. The issue to be decided is whether their positive values outweigh their negative values. In making this decision, we must remember that alternatives to tax incentives exist even for a timid government; the guarantee of debts and the bearing of financial burdens of interest and carrying charges are among them.

\section{Conclusion}

The argument against incentives is in microcosm an attack on the entire irrational operation under which all laws-not just tax statutes-are drafted, enacted, and applied. Congress, administrators, and the courts have hardly taken the first step toward marshalling our ideas about what social and economic objectives government is seeking inside and outside of the tax structure. It is of course by no means clear that we can succeed in establishing such objectives in terms more meaningful and specific than the easy generalities we see in television and the daily press: to help the poor, reward the loyal, and strive to improve the lot of all. These objectives often conflict with each other and are not always internally consistent. Moreover, the weight to be given to each varies according to the national pulse and the political exigencies of the moment.

So we proceed through a multiplication of objectives. We do not-and in many respects cannot-establish fixed, final, and immutable goals toward which government must aspire. Even such shifting and evanescent goals as we might from time to time appear to follow are not measured against the stated objectives of the tax structure. To the extent that the latter objectives exist they are subject to the same balancing of interests among taxpayers generally, the welfare of the public, and moral considerations held by different classes of people. In addition, we seldom make adequate attempts to forecast, before passing laws, what those laws will do in terms of achieving the objectives proposed. ${ }^{70}$ Finally, even after such laws are passed, we do not examine how they have in fact operated. ${ }^{71}$ Again, it is relevant to complain that the pressure for tax benefits is always very powerful in politics; that it is difficult to consider proposed tax incentives in terms of merit, when the general public is indifferent; that when the poor are supposed to benefit, political persons are intrigued by the prospect of relief; that entrepreneurs who will get the

\footnotetext{
${ }^{70}$ Notable and encouraging exceptions to such a charge are found in the testimony of Secretary Weaver and Undersecretary Barr with respect to S. 2roo as outlined throughout the hearings on that bill.

${ }^{72}$ A former legislative counsel for the Treasury Department has suggested that once a tax incentive has been adopted, the Department should run a cost-effectiveness analysis; one example given was that it might review the tax subsidies given in the form of deductions for the blind as against direct cash subsidies made available to them. The suggestion was also made that studies be undertaken to measure whether, for example, a disproportionate support was given by the taxing statutes and the direct subsidies to amputees as compared to the blind. See Stone, supra note II, at I4-I8. The author emphasizes that such an analysis is diffcult; the quantification of the results of a statute, measured against a value judgment underlying the law, presents obvious complexities. Other difficulties are extensive and have been discussed from time to time throughout this article.
} 
tax advantage are understandably enthusiastic about passing a portion of their tax burden off to the generality of the taxpayers; and, in short, that democracy has not yet reached perfection.

The result of all the foregoing is this: It is not now realistic to expect the tax statutes to be restructured in a persuasive and coldly logical form. Still less is it reasonable to expect such progress with respect to tax incentives. It is not possible to measure precisely the ebb and flow of the needs, desires, and deserts of citizens in terms of social, economic, and tax objectives. It is difficult to predict what tax measures would accomplish even objectives on which all would agree. And it cannot be denied that current conclusions about tax statutes, including tax incentives, are essentially intuitive.

All of this is far from fatal, as the relative effectiveness of the federal tax structure demonstrates. There is no occasion for despair. Nevertheless, there is still much that can be done.

More than anything else we need to develop techniques by means of which we can predict the effects of tax statutes with more accuracy. Particularly should we seek ways to forecast human behavior. Perhaps it will become possible-through econometrics, psychiatry, statistical studies, the Brookings report, advances in abstract political economy, computer science, and new investigative techniquesactually to measure what kind of conduct, if any, is being or might be encouraged by present and proposed segments of the tax structure. ${ }^{72}$ One result of these advances would be the containment, to a considerable degree, of the power of the pressure group. What is more important, if taxpayer conduct can be accurately related to certain statutory provisions or proposed provisions, truly informed decisions can be made.

\footnotetext{
${ }^{72}$ Progress is being made: Note the studies, for example, of Klein, supra note 42; Taussig, supra note 46 ; and the activities of the American Bar Association's Committee on Substantive Tax Reform, as outlined by Dean Galvin, History of the Stsbstantive Tax Reform Project, in Studies in Substantivi TAX REForM, supra note 13 , at 3. The remainder of this latter work reveals fascinating empirical studies now underway. Serious studies are also underway by the Treasury Department. See the unpublished study of Professor Ricks, Real Estate Investment: The Investment Process, Investment Performance and Federal Tax Policy (I969).
} 